\title{
Thrombospondin 2 Functions as an Endogenous Regulator of Angiogenesis and Inflammation in Rheumatoid Arthritis
}

\author{
Yong Wook Park, ${ }^{*}$ Young Mo Kang, ${ }^{*}$ \\ Joe Butterfield, ${ }^{*}$ Michael Detmar, ${ }^{\dagger}$ \\ Jörg J. Goronzy, ${ }^{*}$ and Cornelia M. Weyand* \\ From the Department of Medicine," Lowance Center for Human \\ Immunology, Emory School of Medicine, Atlanta, Georgia; and \\ the Department of Dermatology, Massachusetts General Hospital \\ and Harvard Medical School, ${ }^{\dagger}$ Boston, Massachusetts
}

Thrombospondin 2 (TSP2), a matricellular protein with a primary role in modulating cell-matrix interactions, has been implicated in tissue repair and foreign body responses. Here we show that TSP2 has regulatory function in the chronic inflammatory lesions of rheumatoid arthritis. Tissue TSP2, produced by synovial fibroblasts, endothelial cells, and macrophages correlated not only with the intensity of angiogenesis but also with the architecture of lymphoid infiltrates. Synovial tissues with diffuse inflammatory infiltrates had high levels of TSP2, whereas synovial tissues with ectopic germinal center reactions and $T$ cell-B cell aggregates produced low levels. Cell-based gene therapy with TSP2 was used to examine the in vivo effects of the matrix protein on neoangiogenesis and lymphoid organization. Human synovium-severe combined immunodeficiency (SCID) mouse chimeras were treated with TSP2-transfected fibroblasts deposited into the peritoneum. Overexpression of TSP2 led to the accumulation of TSP2 protein in the inflamed synovium and resulted in a prompt inhibition of lesional vascularization. Beside its anti-angiogenic activity, TSP2 also suppressed the production of the proinflammatory mediators, interferon- $\gamma$ and tumor necrosis factor- $\alpha$, and induced the depletion of tissueresiding $T$ cells. We propose that TSP2 is an endogenous regulator of angiogenesis and autoimmune inflammation in the synovium and represents a protective mechanism preventing ectopic lympho-organogenesis and persistent inflammation in this tissue site. (Am J Patbol 2004, 165:2087-2098)
Rheumatoid arthritis (RA), a systemic autoimmune syndrome, manifests with chronic inflammation of the synovium that causes irreversible damage of tendons, cartilage, and bone. ${ }^{1,2}$ One of the characteristics of the synovial inflammatory infiltrates is their high degree of organization and their resemblance with structures in lymphoid organs. ${ }^{3,4}$ The arrangements of $T$ cells and $B$ cells in rheumatoid synovitis are organized and include the formation of ectopic germinal centers (GCs), the assembly of $T$ cell-B cell aggregates, and a seemingly diffuse pattern of tissue infiltration. ${ }^{5-7}$ Dendritic cells, macrophages, and endothelial cells participate in the process of ectopic lymphoid organogenesis. ${ }^{8}$ The aberrant lymphoid microstructures in the synovial membrane have in common that they are T cell-dependent, exemplified by ectopic GCs formed in a subset of patients. 9,10 The strongest genetic risk factor for RA has been mapped to the human histocompatibility leukocyte antigen region also implying a role for defective T-cell regulation in disease pathogenesis. ${ }^{11,12} \mathrm{~T}$ cells from patients with RA acquire new regulatory receptors and thus can respond to novel cues in the synovial microenvironment. ${ }^{13-15}$ In the end phase of the disease process, a multitude of effector pathways are used, as demonstrated in animal models of inflammatory arthritis. ${ }^{16,17}$

Careful analysis of the microanatomy of the synovial lesions has been helpful in categorizing cases of rheumatoid synovitis into three major types. ${ }^{6,18}$ Approximately $50 \%$ of all patients have diffuse synovitis, in which tissueinfiltrating $\mathrm{T}$ cells, B cells, and macrophages appear to be nonorganized. In one-quarter of patients, T cells and $B$ cells are arranged in lymphoid clusters, so-called aggregates. These aggregates lack follicular dendritic cells and B-cell proliferation and do not represent primary follicles. The remaining quarter of patients form typical

Supported in part by grants from the National Institutes of Health (RO1 AR 42527, RO1 Al 44142, RO1 AR 41974, and RO1 EY 11916).

Accepted for publication September 1, 2004

Address reprint requests to Cornelia M. Weyand, M.D., Ph.D., Lowance Center for Human Immunology, Emory University School of Medicine, Room 1014 Woodruff Memorial Research Building, 101 Woodruff Circle, Atlanta, GA 30322. E-mail: cweyand@emory.edu. 
GC reactions. Lymphotoxin (LT)- $\beta$, derived from mantle zone $B$ cells and a small population of T cells, and the chemokine, CXCL13, have been identified as critical factors in the process of synovial GC formation. ${ }^{6}$ Also, $\mathrm{CD} 8^{+} \mathrm{T}$ cells positioned in the mantle zone are necessary to maintain functional GCs in the synovial microenvironment. ${ }^{9}$

The neogenesis of highly complex lymphoid structures in the nonlymphoid synovial tissue site emphasizes the contribution of antigen $(\mathrm{Ag})$ recognition and chronic stimulation of $T$ cells and B cells. Nevertheless, there is increasing evidence that cell-cell and cell-matrix interactions are pivotal components of autoimmunity. Several different traits are almost certainly required to allow the immune system to built chronically activated units at nonlymphoid tissue sites. Components of the specific tissue site, such as resident cell populations and matrix proteins, are suspected to be involved in defining tissue susceptibility for chronic inflammation. One example is the induction of angiogenesis, a process considered essential in the establishment of ectopic lymphoid organizations and the expansion of the synovial membrane into an erosive neotissue. ${ }^{19-21}$ Changes in the regulation of endothelial growth may even be a very early checkpoint in the process of initiating and maintaining chronic inflammatory infiltrates in the synovial membrane..$^{22}$ It has been proposed that the switch to the angiogenic phenotype, a term coined for tumorigenesis but equally applicable for the process of chronic inflammation, begins with a disturbance in the balance of positive and negative regulators of endothelial growths. ${ }^{23}$ Vascular endothelial growth factor (VEGF), a major proangiogenic mediator, has been described to be present in rheumatoid synovium. ${ }^{24} \mathrm{~A}$ number of other mediators, including CXC chemokines, are known to be regulators of angiogenesis and promote the growth of new blood vessels. ${ }^{25,26}$ The action of proangiogenic factors is counterbalanced by inhibitors of angiogenesis. A panel of naturally occurring angio-inhibitory proteins has been identified, including thrombospondin 1 (TSP1), ${ }^{27}$ TSP2, ${ }^{28}$ angiostatin, ${ }^{29}$ endostatin, ${ }^{30}$ and vasostatin. ${ }^{31}$ The biological role of such endogenous inhibitors in rheumatoid synovitis has remained undetermined. In particular, it is not known whether the angioinhibitory matrix proteins, TSP1 and TSP2, modulate the process of microvessel formation in rheumatoid synovitis and how synovium-specific production of angiogenic inhibitors contributes to the target tissue susceptibility of the synovial space.

The majority of tissue-resident cells in rheumatoid synovitis are synovial fibroblasts. It is not known how these cells are involved in regulating the process of ectopic lymphoid organogenesis or how they affect the process of angiogenesis. Fibroblasts have been identified as the major source of TSP2, a secreted extracellular matrix glycoprotein. ${ }^{32}$ TSP2 is a 420-kd homotrimeric molecule that is less important in the structural integrity of the matrix but instead modulates the bioavailability and activity of growth factors and enzymes in the pericellular environment. ${ }^{28,33,34}$ Like TSP1, TSP2 is known to have anti-angiogenic function but additional biological activities have been identified in TSP2 $2^{\text {null }}$ mice. TSP2-deficient mice have connective tissue abnormalities with disorganization of collagen fibrils, increased bone density, and abnormal platelet function leading to a bleeding diathesis. ${ }^{35}$ A role for TSP2 as a physiological inhibitor of angiogenesis has been documented by the increased capillary density in dermis, subcutaneous adipose tissue, and thymus of TSP2-deficient mice with even more impressive results in response-to-injury models in which healing and tissue repair depend on rapid vascularization. ${ }^{36,37}$ In the mouse, TSP2 deficiency has been shown to dramatically enhance the susceptibility to skin carcinogenesis ${ }^{38}$ and to prolong the inflammatory response of delayed-type hypersensitivity reactions in the skin. ${ }^{39}$ Here we report that TSP2 is differentially expressed in rheumatoid synovitis and that tissue expression is not only closely associated with angiogenesis but the architecture of lymphoid microstructures. Overexpression of TSP2 in vivo leads to a rapid down-regulation of vascular density, but more importantly, disrupts inflammatory infiltrates and suppresses rheumatoid synovitis. Our findings suggest that the fibroblast-derived matricellular protein TSP2 functions as an endogenous inhibitor of synovial inflammation.

\section{Materials and Methods}

\section{Study Population and Histopathological Evaluations}

Synovial tissues were obtained from 106 patients with active RA who fulfilled the American College of Rheumatology 1987 revised criteria for RA and who underwent joint surgery. The protocol was approved by the Mayo Clinic Institutional Review Board and all patients provided written informed consent. Hematoxylin sections of the synovial tissue samples were analyzed by one hemopathologist and each synovial tissue was classified into follicular, aggregate, or diffuse synovitis as previously described. ${ }^{6,9}$ Mean disease duration was $14.9 \pm 8.7$ years in the patient subsets with follicular synovitis, $13.6 \pm 7.4$ years in the patients with aggregate synovitis, and $15.0 \pm 7.7$ years in the patients with diffuse synovitis.

\section{Cell Culture}

Primary cultures of fibroblast-like synoviocytes were obtained from synovial tissue of RA patients. Fresh tissues were cut into small pieces and digested with $500 \mu \mathrm{g} / \mathrm{ml}$ of collagenase (Sigma, St. Louis, MO). Single-cell suspension was prepared and nonadherent cells were washed off after 3 days of culture. Fibroblast-like synoviocyte lines were used for experiments after four to six passages. TSP2-transfected NIH 3T3 fibroblasts and vectortransfected NIH 3T3 fibroblasts have been described previously. ${ }^{40}$ All clones and lines were cultured with Dulbecco's modified Eagle's medium (BioWhittaker, Walkersville, MD) containing 10\% fetal calf serum (Summit Biotech, Fort Collins, CO), $2 \mathrm{mmol} / \mathrm{L}$ L-glutamine, 100 $\mathrm{U} / \mathrm{ml}$ penicillin, and $100 \mu \mathrm{g} / \mathrm{ml}$ streptomycin sulfate (Life Technologies, Grand Island, NY) in a humidified $5 \% \mathrm{CO}_{2}$ incubator. 
Table 1. Nucleotide Sequences of PCR Primers

\begin{tabular}{|c|c|c|}
\hline Target & Sequence $\left(5^{\prime} \rightarrow 3^{\prime}\right)$ & Annealing $\left({ }^{\circ} \mathrm{C}\right)$ \\
\hline \multirow[t]{2}{*}{ VEGF } & 5'-CATCCAATCGAGACCCTG-3' & 55 \\
\hline & 5'-GGTTTGATCCGCATAATCT-3' & \\
\hline \multirow[t]{2}{*}{ Ang1 } & 5'-CCTGATCTTACACGGTGC-3' & 55 \\
\hline & 5'-GCTTTCATAATCGCTTCT-3' & \\
\hline \multirow[t]{2}{*}{ Ang2 } & 5'-ACGGACCAAAGCAAGACC-3' & 55 \\
\hline & 5'-GGTTGTGACAGCAGCGTC-3' & \\
\hline \multirow[t]{2}{*}{ TSP1 } & 5'-ATTCCAGAGTCTGGCGGA-3' & 55 \\
\hline & 5'-TTCTGTCCGCACAGCATC-3' & \\
\hline \multirow[t]{2}{*}{ TSP2 } & 5'-TATGCCAAACAGGAACGA-3' & 55 \\
\hline & 5'-TTTAATGAAGTATCCCAACG-3' & \\
\hline \multirow[t]{2}{*}{ IFN- $\gamma$} & 5'-ACCTTAAGAAATATTTTAATGC-3' & 55 \\
\hline & 5'-ACCGAATAATTAGTCAGCTT-3' & \\
\hline \multirow[t]{2}{*}{ TNF- $\alpha$} & 5'-CTTTGGGATCATTGCCCTGTG-3' & 60 \\
\hline & 5'-CGAAGTGGTGGTCTTGTTGCT-3' & \\
\hline \multirow[t]{2}{*}{$\beta$-Actin } & 5'-ATGGCCACGGCTGCTTCCAGC-3' & 55 \\
\hline & 5'-CATGGTGGTGCCGCCAGACAG-3' & \\
\hline
\end{tabular}

\section{Generation of Human Synovium-Severe Combined Immunodeficiency (SCID) Mouse Chimeras and Adoptive Transfer Experiments}

This protocol was reviewed and approved by the Mayo Clinic Animal Care and Use Committee. NOD.CB17-Prk$\mathrm{dc}^{\text {scid }} / \mathrm{J}$ mice (nonobese severe combined immunodeficiency; NOD-SCID) were from The Jackson Laboratory, Bar Harbor, ME, and used at age 6 to 8 weeks. For tissue implantation, the mice were anesthetized with a $50 \mathrm{mg} / \mathrm{kg}$ pentobarbital (Abbott Laboratories, North Chicago, IL) intraperitoneal injection and methoxyflurane (Medical Developments Australia, Springvale, Victoria, Australia) inhalation. Pieces of human synovial tissue with inflammatory infiltrates were placed into a subcutaneous pocket on the dorsal midline. In this model, complete tissue engraftments occur with 1 week. To examine the effects of TSP2 overexpression, synovium-SCID mouse chimeras were generated and $2 \times 10^{6}$ TSP2- or vector-transfected NIH 3T3 fibroblasts were intraperitoneally injected 7 days after tissue implantation. Synovial tissue grafts were explanted 10 days after injection and embedded in OCT compound (Tissue-Tek; Sakura Finetek, Torrence, CA) for immunohistochemistry or shock-frozen in liquid nitrogen for RNA analysis.

\section{RNA Isolation and Real-Time Reverse Transcriptase-Polymerase Chain Reaction (PCR)}

Total RNA was extracted from synovial tissue specimens using TRIzol (Invitrogen Life Technologies, Grand Island, NY), reverse-transcribed into cDNA using AMV reverse transcriptase (Roche Molecular Biochemicals, Indianapolis, IN). cDNA was adjusted to contain equal numbers of $\beta$-actin transcripts as determined by real-time PCR. Primer sequences for real-time reverse transcriptasePCR are listed in Table 1. Transcripts for each gene were quantified using the Mx 4000 PCR instrument (Stratagene, Cedar Creek, TX). cDNA (1 $\mu$ l) was mixed with a total volume of $50 \mu$ l of SYBR Green master mix ( $5 \mu$ l of
10× PCR buffer, $2.5 \mathrm{mmol} / \mathrm{L} \mathrm{MgCl}_{2}, 0.2 \mathrm{mmol} / \mathrm{L}$ each dNTPs, $0.025 \%$ bovine serum albumin, $0.2 \mu \mathrm{l}$ of $5 \mathrm{U} / \mu \mathrm{l}$ Plt. Taq, 1:20,000 SYBR Green, and 0.1 to $0.2 \mu \mathrm{mol} / \mathrm{L}$ of each primer). PCR amplification protocol involved 40 cycles of denaturation at $95^{\circ} \mathrm{C}$ for 30 seconds, primer annealing at $55^{\circ} \mathrm{C}$ or $60^{\circ} \mathrm{C}$, and primer extension at $72^{\circ} \mathrm{C}$ for 60 seconds. PCR reactions for each sample were done in triplicate. The level of gene expression was determined by interpolation with a standard curve and expressed as the number of target gene copies per $2 \times 10^{5} \beta$-actin copies.

\section{Western Blot Analysis}

Synovial tissues were shock-frozen in liquid nitrogen. The frozen tissues were sliced very thinly and homogenized in lysis buffer [50 mmol/L Tris-Cl, pH 7.6, $150 \mathrm{mmol} / \mathrm{L} \mathrm{NaCl}$, $1.0 \%$ Triton $\mathrm{X}-100,0.5 \mathrm{mmol} / \mathrm{L}$ phenylmethyl sulfonyl fluoride, $1 \mathrm{mmol} / \mathrm{L}$ sodium orthovanadate, and protease inhibitor cocktail (Boehringer Mannheim, Indianapolis, IN)]. Cultured fibroblasts were incubated with the lysis buffer. Cell and tissue lysates were collected after centrifugation at $10,000 \times g$ for 5 minutes. The amount of total protein in each sample was quantified with the Protein Assay Kit II (Bio-Rad Laboratories, Richmond, CA). Lysates were analyzed by sodium dodecyl sulfate-polyacrylamide gel electrophoresis and transferred onto a nitrocellulose membrane. The membranes were then immunoblotted with goat polyclonal anti-TSP2 antibody (Ab) (1:300; Santa Cruz Biotechnology, Santa Cruz, CA) or goat polyclonal anti-actin Ab (1:200, Santa Cruz Biotechnology). Blots were developed using horseradish peroxidase-conjugated mouse anti-goat IgG (1:1000, Santa Cruz Biotechnology) and the SuperSignal West Pico chemiluminescent detection system (Pierce Chemical Co., Rockford, IL).

\section{Immunocytochemistry and Immunohistochemistry}

For immunocytochemistry, synovial fibroblasts cultured on Lab-Tek chamber slides (Nunc Inc., Naperville, IL) were fixed in $4 \%$ paraformaldehyde for 10 minutes and then permeabilized in phosphate-buffered saline/ Tween-20 (0.2\%) for 6 minutes. Cells were incubated in normal rabbit serum for 20 minutes (Invitrogen Life Technologies, Carlsbad, CA) and stained with goat polyclonal anti-TSP2 Ab (1:300, Santa Cruz Biotechnology) at $4^{\circ} \mathrm{C}$ overnight, followed by incubation with biotinylated rabbit anti-goat IgG, and developed with Vectastain Elite ABC peroxidase reagents and immunofluorescent Vector Red (Vector Laboratories, Burlingame, CA). For immunohistochemistry, frozen synovial tissues embedded in OCT compound were cut into $5-\mu \mathrm{m}$ sections, fixed in cold acetone for 10 minutes, dried for 30 minutes, and soaked in $1 \%$ paraformaldehyde solution for 3 minutes. Endogenous peroxidase was blocked with $0.3 \% \mathrm{H}_{2} \mathrm{O}_{2}$ in $0.1 \%$ sodium azide. Nonspecific binding was blocked with normal rabbit serum or normal goat serum. The following Abs were used for immunohistochemistry: goat polyclonal anti-TSP2 (1:300, Santa Cruz Biotechnology); 
mouse monoclonal anti-CD146 (1:300, P1H12; Chemicon, Temecula, CA); mouse monoclonal anti-CD3 (1:300, UCHT1; DAKO, Carpinteria, CA); and mouse monoclonal anti-CD68 (1:100, PG-M1; DAKO). Sections were incubated with primary Abs for 1 hour at room temperature. Biotinylated rabbit anti-goat IgG (Vector Laboratories) and goat anti-mouse IgG (1:200, DAKO) were used as secondary Abs. Sections were developed with Vectastain Elite ABC peroxidase reagents and 3,3'-diaminobenzidine tetrahydrochloride (Sigma-Aldrich). For double labeling, the sections were incubated with a second primary $A b$ and developed using Vectastain $A B C$ alkalinephosphatase reagents and Vector Red or Vector Blue (Vector Laboratories). For all staining experiments, control stains with isotype-matched Ab were included.

\section{Computer-Assisted Morphometric Analysis of Blood Vessels and $\mathrm{CD}^{+}{ }^{+} \mathrm{T}$ Cells}

Representative sections were obtained from synovial tissue blocks and stained with anti-CD146 Ab or anti-CD3 Ab. Images were captured with an AxioCam digital cam- era and analyzed with the KS400 image analysis system (Carl Zeiss, Inc., Oberkochen, Germany).

\section{Statistical Analysis}

Quantitative cytokine transcript data and vascular morphometric data were compared using the Wilcoxon's signed-rank test (SigmaStat; SPSS Inc., Chicago, IL).

\section{Results \\ Vascularization Pattern in Different Types of Rheumatoid Synovitis}

The relationship between the architecture of the lymphoid organizations in rheumatoid synovitis and the pattern of angiogenesis was investigated in tissue sections from a cohort of 62 patients. Staining for the endothelial junction molecule CD146 was used to quantify vessel density. All blood vessels expressing CD146 were also positive for the scaffolding molecule CD31. A subset of $\mathrm{CD}_{146^{+}}$
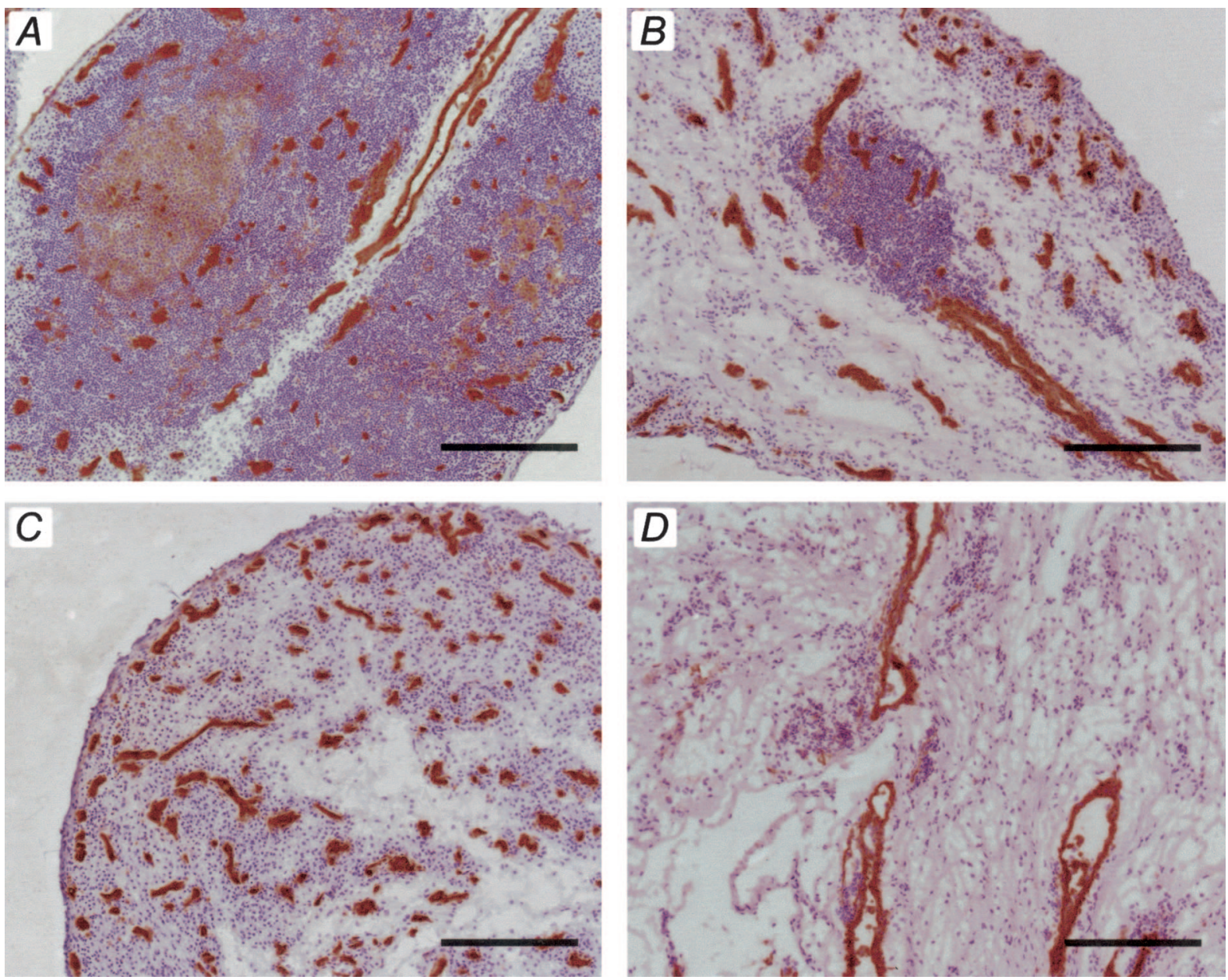

Figure 1. Patterns of vascularization in rheumatoid synovitis. Synovial tissue sections from 62 patients with RA were processed for immunohistochemical staining with anti-CD146 Ab (brown, expressed on endothelial cells). A: Synovial tissues with typical GC reactions were densely vascularized with microvessels arranged around the GCs and distributed throughout the tissue. B: A similar high density of microvessels was found in tissues containing T cell-B cell aggregates that lacked GC reactions. C: In tissues with T cell-B cell aggregates, the vascularization pattern was maintained in tissue areas without T cell-B cell clusters. D: Biopsies with diffuse synovitis typically had lower densities of blood vessels. Scale bars, $200 \mu \mathrm{m}$. 


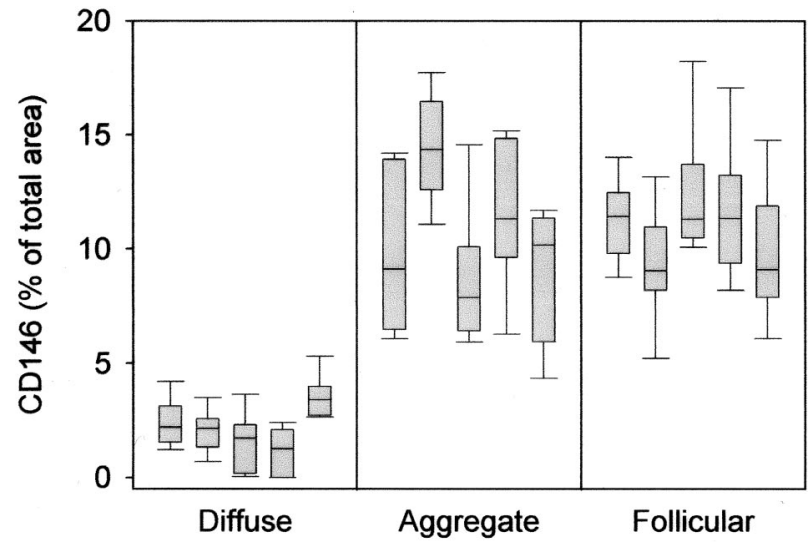

Figure 2. Computer-assisted morphometric analysis of vascularization patterns in rheumatoid synovitis. Frozen sections were stained with anti-CD146 $\mathrm{Ab}$ to visualize endothelial cells, as described in Figure 1. At least 10 distinct sections from each patient were analyzed and the area stained with antiCD146 was quantified. Shown are the results for five different patients with diffuse, aggregate, and follicular synovitis, respectively. Results for each patient are represented by a box plot with median, 25 th, and 75 th percentiles as boxes and 10th and 90th percentiles as whiskers. In tissues with T cell-B cell aggregates and $\mathrm{GC}^{+}$follicles, vascular densities were more than threefold higher than in tissues with diffuse infiltrates $(P<0.001$ aggregate versus diffuse; $P<0.001$ follicular versus diffuse)

endothelial cells stained only weakly for von Willebrand factor (data not shown). As previously described, ${ }^{5,6}$ the tissues displayed different types of lymphoid microstructures. Each of the lymphoid microstructures was associated with a typical pattern of angiogenesis (Figure 1). Tissues containing classical GC reactions were densely vascularized with a mixture of large and small blood vessels (Figure 1A). Within the GC, microvessels were unusual but occasionally a blood vessel was placed centrally. There was a clear tendency for smaller vessels to be arranged in a ring-like formation at the outer edge of the T-cell zones. The high angiogenic density was maintained in tissue areas that did not contain fully developed GCs.

Tissues with $T$ cell-B cell aggregates were characterized by a high density of newly formed vessels, distributed throughout the stroma, and often positioned close to the lining cell layer (Figure 1B). No obvious topographical relationship was observed between the lymphoid clusters and the blood vessels. Tissue areas that were free of lymphoid aggregates displayed the same high density of $\mathrm{CD}_{146}{ }^{+}$vessels (Figure 1C).

A different pattern of angiogenesis emerged for tissues with diffuse synovitis (Figure 1D). Vessels were less numerous in such specimens. In some patients with diffuse synovitis, smaller vessels were rare and the distance between the synovial surface and CD146 ${ }^{+}$endothelial cells was larger than in the other types of synovitis. Typically, extended areas of the tissue were free of any microvessels. Positioning of lymphocytes or macrophages did not predict the placing of blood vessels.

To quantify the differences in angiogenesis, computerassisted morphometric analysis of CD146-stained sections was used (Figure 2). A minimum of 10 distinct sections was analyzed for each patient. In samples with diffuse synovitis, the total vascular area ranged from 2 to $4 \%$. In patients with aggregate synovitis, CD146-stained areas were fourfold to fivefold higher $(P<0.001$ diffuse

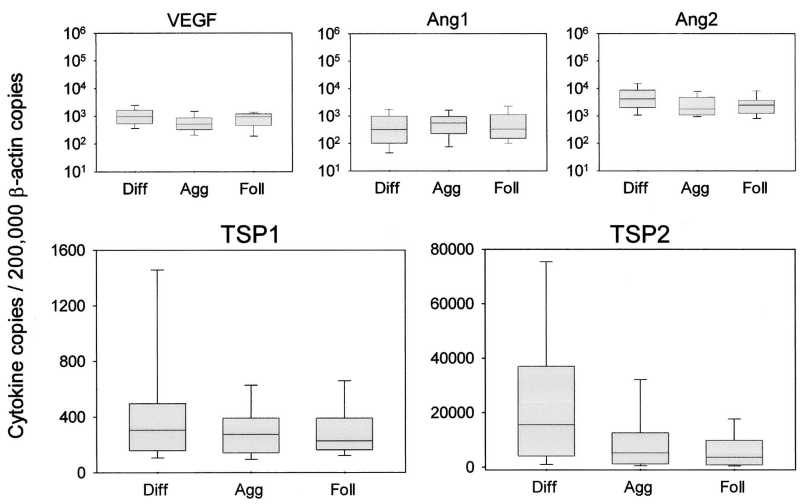

Figure 3. Synovial tissues with diffuse synovitis produce higher levels of TSP2. Synovial tissue biopsies from 82 patients with RA were divided according to the type of synovitis and analyzed for the production of pro- and anti-angiogenic mediators. Diffuse synovitis was present in 37 patients, 31 patients had aggregate synovitis, and $\mathrm{GC}^{+}$follicles were detected in 14 patients. cDNA was prepared from tissue extracts and transcripts for $\beta$-actin and each of the mediators were determined by quantitative real-time PCR. Transcript concentrations were adjusted relative to $2 \times 10^{5} \beta$-actin copies. Results are shown as box plots with medians, 25 th, and 75 th percentiles as boxes and 10th and 90th percentiles as whiskers. Copy numbers for VEGF-, Ang1-, Ang2-, and TSP1-specific sequences were similar in all types of rheumatoid synovitis. Levels of TSP2 transcripts were significantly higher in tissues with diffuse synovitis $(P<0.01$ diffuse versus follicular; $P<0.05$ diffuse versus aggregate).

versus aggregate). In follicular synovitis with GCs, 10\% of the tissue area was positive for the endothelial marker CD146 $(P<0.001$ diffuse versus GCs, $P=$ NS aggregate versus GCs). No difference was found for the distribution of vessel sizes in the three different types of synovitis (data not shown).

\section{Expression of Pro- and Anti-Angiogenic Mediators in Rheumatoid Synovitis}

Neoangiogenesis in rheumatoid synovitis is driven by multiple proangiogenic mediators, including VEGF, angiopoietin 1 (Ang1), and Ang2. ${ }^{24-26}$ To address the question whether the differences in the microvessel density resulted from variations in the production of pro- and anti-angiogenic factors, we determined the tissue expression of VEGF, Ang1, and Ang2 in 81 synovial tissue biopsies (Figure 3). Thirty-seven patients had diffuse synovitis, aggregates were found in 31 patients and classical GCs were detected in 14 samples. Transcripts specific for Ang1 were present at similar levels in all tissue types. Ang2-specific sequences were rapidly detected, with the highest levels in diffuse tissues. VEGF production was similar in diffuse and follicular tissues and lower in aggregate tissues. Thus, tissues with higher vascularization did not express higher levels of proangiogenic factors. On the contrary, there was a trend for Ang2, and for aggregate tissues also for VEGF, to be expressed at lower amounts. This finding did not explain why biopsies with diffuse synovitis had a significantly lower density of angiogenic vessels.

To explore whether the correlation of synovitis type and vascularization pattern was a reflection of differences in the production of anti-angiogenic mediators, we analyzed the tissue expression of TSP1 and TSP2. The tis- 


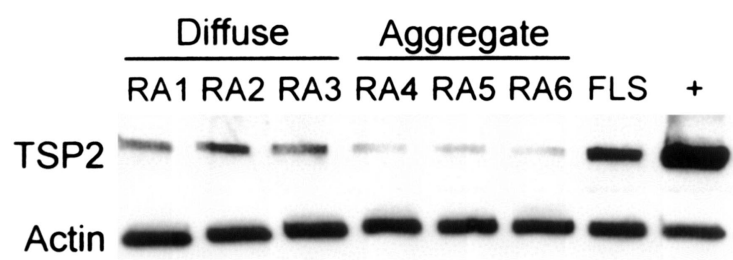

Figure 4. Protein expression of endogenous TSP2 in rheumatoid synovitis. Western blot analysis of tissue extracts was used to compare the production of TSP2 protein in different types of rheumatoid synovitis. Representative results from five different experiments are shown. Three tissue samples (RA1, RA2, RA3) had diffuse synovitis and three tissues (RA4, RA5, RA6) contained $\mathrm{T}$ cell-B cell aggregates. Actin served as a loading control. The positive control was derived from TSP2-transfected NIH 3T3 fibroblasts. High expression of TSP2 protein was typical for diffuse synovitis and in vitro expanded synovial fibroblast lines.

sues contained similar concentrations of TSP1-specific transcripts. mRNA for TSP2 was highly abundant in the synovial extracts. Highest levels were present in diffuse synovitis samples, whereas tissues with organized lymphoid microstructure displayed low levels of TSP2 transcripts. TSP2-specific copies were threefold higher in diffuse than in aggregate tissues $(P<0.05)$ and fivefold higher than in follicular samples $(P<0.01)$. If one considers the balance between the proangiogenic and antiangiogenic markers, biopsies with diffuse synovitis had the lowest ratio comparing VEGF, Ang1, or Ang2 with TSP2, whereas aggregate and GC-containing tissue sections had consistently higher ratios (data not shown).

To confirm that TSP2 production was higher in diffuse tissues than those with organized lymphoid structures, we performed Western blotting of tissue extracts. Representative results are given in Figure 4. Protein expression of endogenous TSP2 was markedly higher in tissues derived from patients with diffuse synovitis. High concentrations of TSP2 protein were also found in fibroblasts lines established from synovial tissue digests. The correlation between TSP2 expression and tissue architectures with different degrees of neoangiogenesis raised the possibility that the abundance of neoangiogenic vessels in tissue specimens from patients with aggregate and follicular synovitis is a result of insufficient TSP2 production.

\section{Cellular Origin of TSP2 in Rheumatoid Synovitis}

If TSP2 functions as a physiological inhibitor of angiogenesis in synovium, it is important to understand its cellular origin. Consistent with the notion that TSP2 expression in vivo is associated with organs rich in connective tissue, ${ }^{28,32}$ fibroblast-like synoviocyte lines established from synovial tissue showed strong staining for TSP2 protein, mostly in a granular pattern (Figure 5A). To identify TSP2-producing cells in the intact tissue, sections from the samples analyzed for mRNA production of proand anti-angiogenic mediators were stained by doubleimmunoenzymatic labeling. As shown in Figure 5, three cellular sources for TSP2 were identified. CD146-expressing endothelial cells were strongly positive for TSP2 (Figure 5, B and C). Synovial fibroblasts, in the lining layer as well as deep in the tissue, stained with TSP2-specific Ab (Figure 5D). Interestingly, TSP2-producing fibroblasts were dispersed throughout and often surrounded by fibroblasts that were negative. The third tissue source, and numerically the least important, was $\mathrm{CD}^{+} 8^{+}$macrophages. TSP2-positive macrophages could be positioned within the lining layer or deep in the stroma (Figure 5, E and F). Macrophages participating in the lymphoid microstructures were typically negative.

\section{Angio-Inhibitory Effects of TSP2 in Rheumatoid Synovitis}

To study whether TSP2 has a role in regulating angiogenesis in the rheumatoid lesion, we generated human synovium-SCID chimeras and overexpressed TSP2 protein through a cell-based gene therapy approach. SynoviumSCID chimeras were injected with $2 \times 10^{6}$ TSP2-transduced NIH 3 T3 fibroblasts intraperitoneally 7 days after the implantation of the human grafts. Control chimeras, which were implanted with synovial tissue from the identical donor, received $2 \times 10^{6}$ vector-transduced $\mathrm{NIH}$ 3T3 fibroblasts. The tissue grafts were removed after 10 days and analyzed for the presence of TSP2 protein. Cellbased gene therapy lead to massive accumulation of TSP2 protein in the synovial grafts (Figure 6). Sections of the explanted grafts were stained with anti-CD146 to evaluate the total vascular area, the vessel density, and the average vessel size. As shown in Figure 7, vessel density and total vascular area declined markedly. Quantitative data obtained by computer-assisted image analysis of five independent experiments are summarized in Figure 7. On overexpression of TSP2 in vivo, vessel density declined from an average of 500 vessels $/ \mathrm{mm}^{2}$ to 319 vessels $/ \mathrm{mm}^{2}(P<0.01)$. The total vascular area was reduced accordingly from $8.1 \%$ in the sham-treated controls to $4.1 \%$ in the TSP2-treated animals $(P<$ $0.001)$. TSP2 therapy did not affect the average vessel size. The microvessels had an average size of $165 \mu \mathrm{m}^{2}$ in the controls and $149 \mu \mathrm{m}^{2}$ in the TSP2-treated grafts $(P=N S)$.

\section{Anti-Inflammatory Effects of TSP2 in Rheumatoid Synovitis}

To examine whether a TSP2-mediated change in angiogenesis correlated with altered function of the inflammatory infiltrates, grafts collected from patients with aggregate and follicular synovitis and treated with TSP2 in the chimeras were analyzed for the density of T-cell infiltrates, the production of the T-cell-derived cytokine interferon (IFN)- $\gamma$ and the production of the proinflammatory monokine tumor necrosis factor (TNF)- $\alpha$. Tissue-infiltrating $T$ cells were quantified by staining sections from the explanted synovial grafts with anti-CD3 Ab. Cell-based gene therapy with TSP2-transduced fibroblasts resulted in a rapid reduction of tissue-infiltrating $T$ cells (Figure 8; A to C), with an average T-cell density of 445 cells $/ \mathrm{mm}^{2}$ in the controls and 202 cells $/ \mathrm{mm}^{2}$ in the TSP2-treated tissues $(P<0.005)$. The loss of tissue-invading $T$ cells was accompanied by a decline in the production of both 


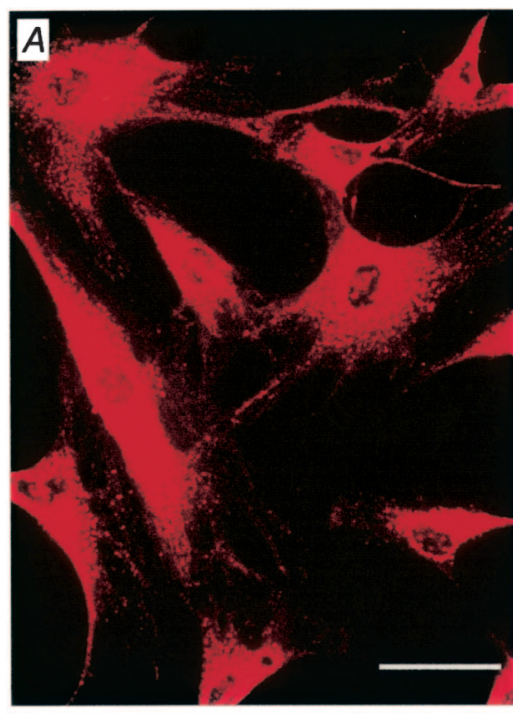

Cultured FLS

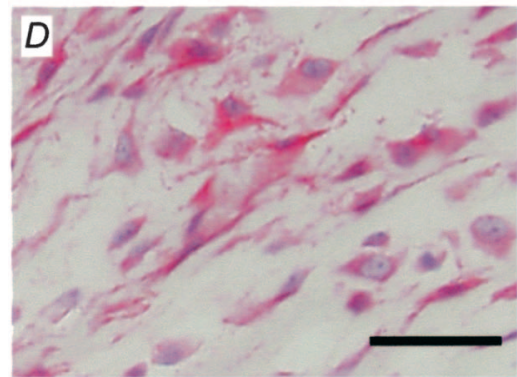

Synovial fibroblasts
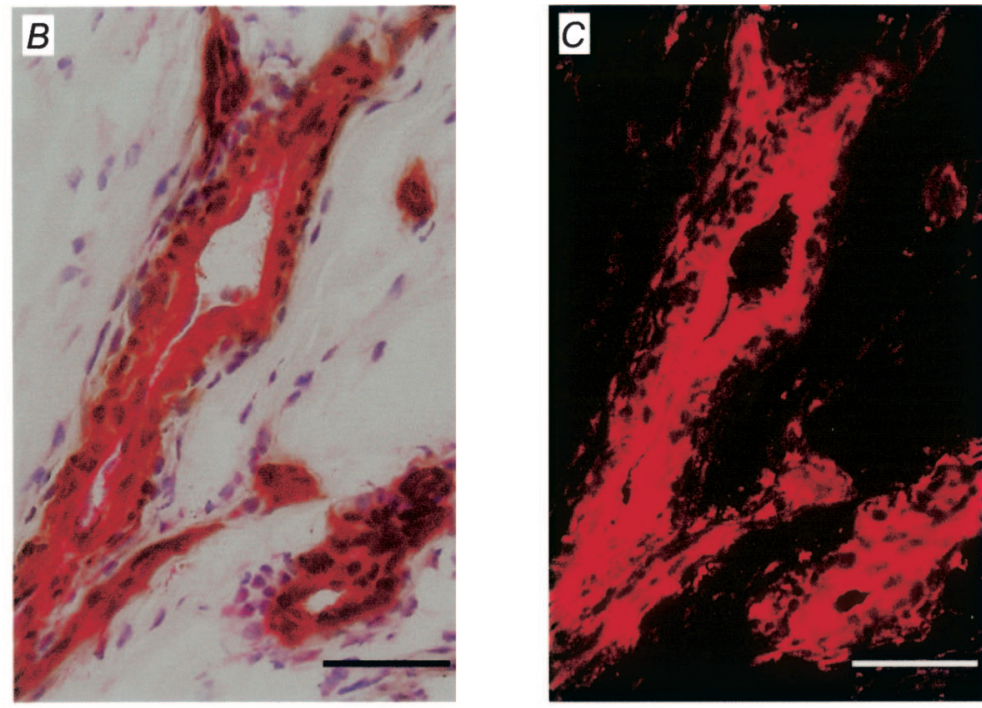

Endothelial cells
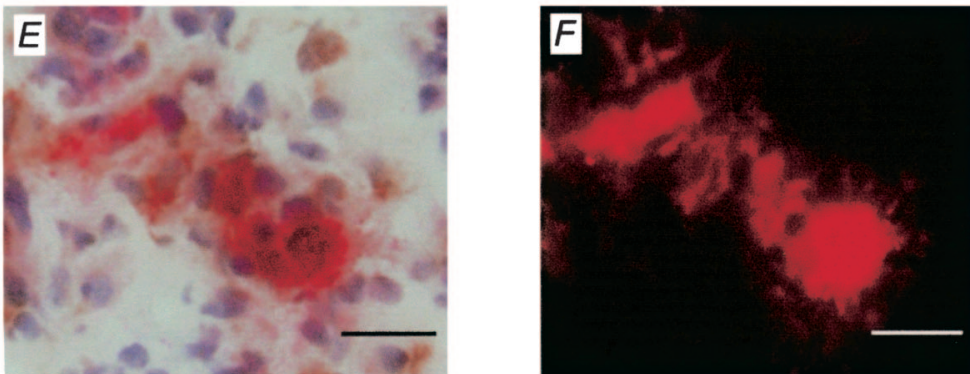

Synovial macrophages

Figure 5. Cellular origin of TSP2 in rheumatoid synovitis. Frozen tissue sections were double-stained with anti-TSP2 Ab and anti-CD146 Ab or anti-TSP2 Ab and anti-CD68 Ab. CD146 and CD68 were visualized with 3,3'-diaminobenzidine tetrahydrochloride (brown) and TSP2 was visualized with Vector Red (red). A. Cultured synovial fibroblasts stained positive for TSP2, typically with a granular cytoplasmic staining. B and C: Endothelial cells expressing CD146 (B) reacted with anti-TSP2 Ab (C). D: Synovial fibroblasts in the tissue produced TSP2. E and F: A low number of CD $68^{+}$macrophages (E) were positive for TSP2 (F). Scale bars: $50 \mu \mathrm{m}(\mathbf{A}-\mathbf{D}) ; 20 \mu \mathrm{m}$ (E, F).

IFN- $\gamma$ and TNF- $\alpha$. As previously shown, synovial tissues vary in the amount of IFN- $\gamma$ produced by the infiltrates. ${ }^{5,9}$ Irrespective of the baseline level, IFN- $\gamma$ production decreased profoundly after TSP2 therapy (Figure 8D). Diminution of IFN- $\gamma$ transcripts in the tissue was even more pronounced than one would expect from the depletion of T cells. TNF- $\alpha$ production was similarly affected. Injection of TSP2-producing fibroblasts lead to an 80 to $90 \%$ drop in the concentrations of TNF- $\alpha$ transcripts compared to the control tissues (Figure 8E). Thus, TSP2 was able to strongly suppress inflammation in rheumatoid lesions.

\section{Discussion}

This study demonstrates an important biological role of the matricellular protein TSP2 as an endogenous regulator of angiogenesis and inflammation in RA. In mice, TSP2 is known to have angio-inhibitory functions and has been implicated in reducing the susceptibility of skin to carcinogenesis. ${ }^{35,38}$ Here, we show that TSP2 is a regulator of chronic tissue inflammation in autoimmune disease. Specifically, we were able to correlate TSP2 production in the synovial tissue site not only with the density of angiogenic microvessels, but also with the formation of highly complex lymphoid architecture. Overexpression of TSP2 protein in a model of human RA suppressed angiogenesis, but also disrupted immune stimulation and inflammation. These data suggest that TSP2, produced by resident cells of the synovial microenvironment, functions as a physiological regulator of vascularization in this tissue site and, more importantly, has a protective role by preventing tissue inflammation.

Rheumatoid inflammation is associated with lymphoid neo-organogenesis. ${ }^{6,18}$ Functionally best characterized are ectopic GCs. Local production of chemokines, particularly the B-cell chemoattractant (CXCL13) and LT, have been demonstrated to have direct impact on the type of lymphoid microstructure that is formed. ${ }^{6,9}$ Data presented here demonstrate that TSP2 is differentially expressed in the different types of synovitis with highest concentrations of transcripts and protein in tissues containing diffuse synovitis. Diffuse synovitis is the least aggressive of the three types, with the lowest levels of proinflammatory cytokines, such as IFN- $\gamma$ and TNF- $\alpha$. In diffuse lesions, angiogenesis was less active than in the two other types. In the TSP2-low variants of rheumatoid 

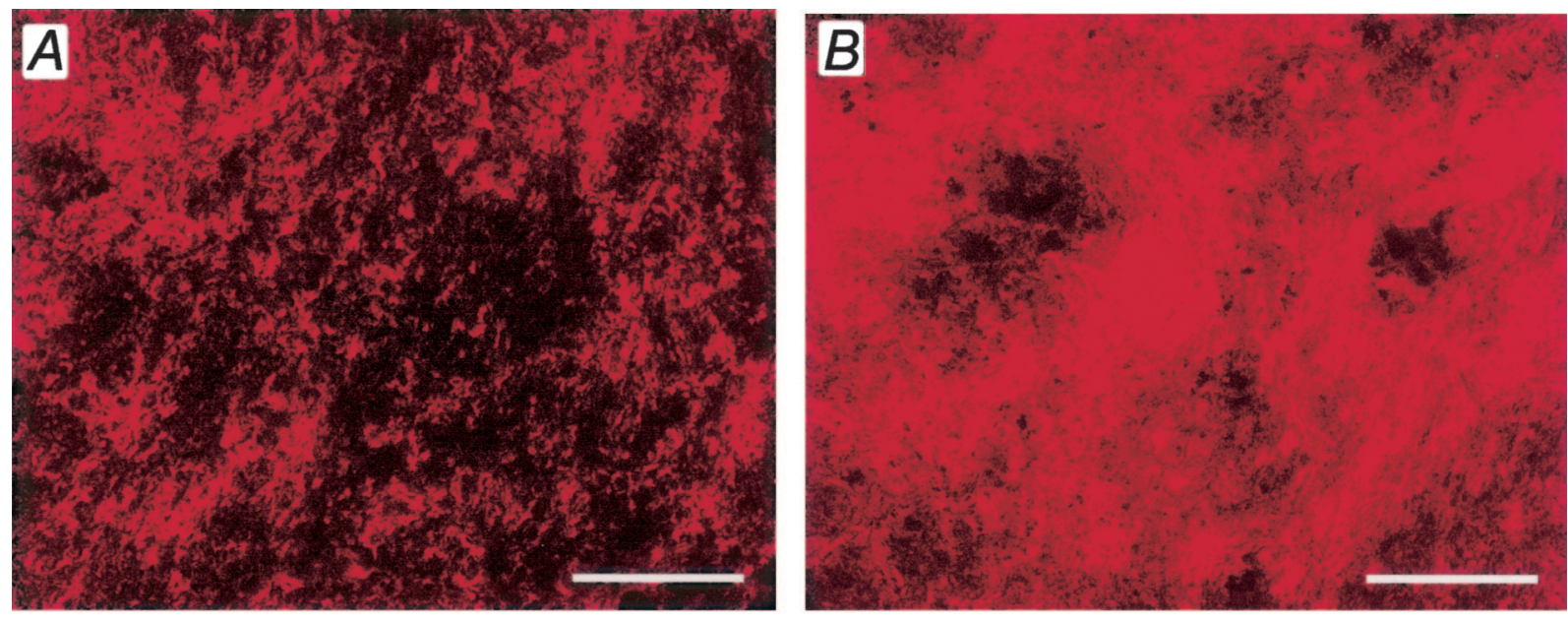

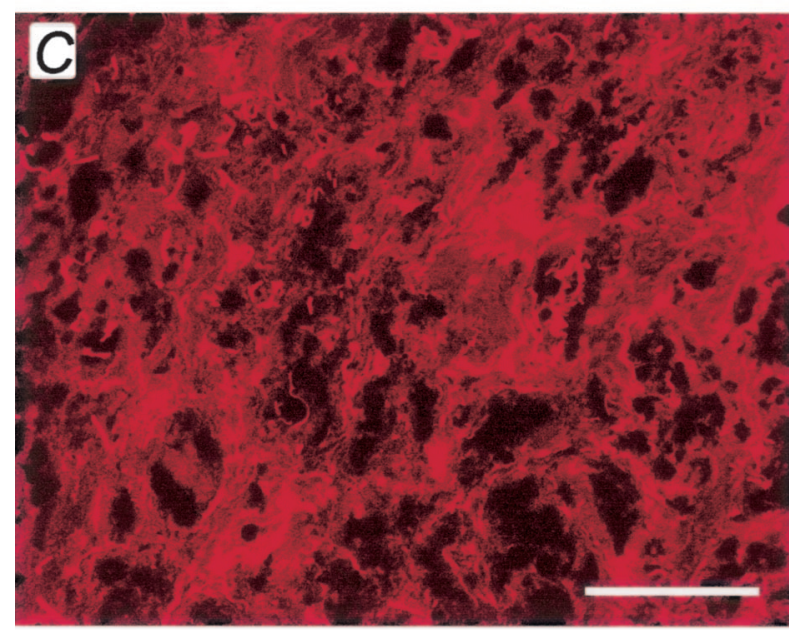

Control

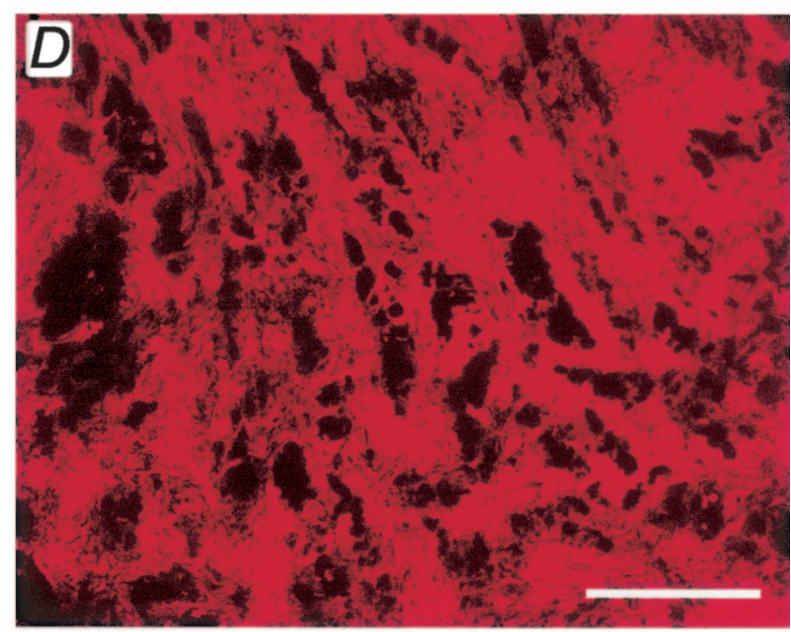

TSP2

Figure 6. Deposition of TSP2 in human synovium after cell-based gene therapy. TSP2-transfected NIH 3T3 fibroblasts or vector-transfected NIH 3T3 fibroblasts were intraperitoneally injected into human synovium-SCID mouse chimeras. Synovial grafts were explanted after 10 days and immunostained with anti-TSP2 Ab (red). Tissue sections from two of five independent experiments are shown. A and $\mathbf{C}$ : Grafts from chimeras injected with vector-transfected fibroblasts contained low levels of TSP2 in the matrix of the synovial tissue. B and D: In chimeras injected with TSP2-transfected fibroblasts, TSP2 protein was densely deposited in the synovial tissue. Scale bars, $100 \mu \mathrm{m}$.

synovitis, vessel density was high in regions that contained lymphoid microstructures but also in regions that had only few nonorganized inflammatory cells. This finding suggests that low TSP2 production preceded the establishment of the lymphoid clusters. Physiological production of TSP2 by synovial fibroblasts may be the mechanism through which the synovial microenvironment not only protects itself from excessive blood vessel formation but may also be a defense mechanism against tissue inflammation.

TSP2 emerged as one of the mediators that regulate the vascularization pattern in rheumatoid synovitis. Likely, additional factors are involved in determining the density of neogenic blood vessels in the expanding synovial layer. However, it is important to note that no correlation was seen between the expression of proangiogenic mediators and the threefold higher density of microvessels in tissues with GCs or T cell-B cell aggregates. Also, TSP2 overexpression in synovium-SCID chimeras had profound effects on microvessel generation within just 10 days after TSP2 gene therapy. These observations sug- gest that TSP2 is an important regulator of endothelial cell growth, particularly in chronic inflammatory lesions.

TSP2 gene therapy has been previously applied in tumor-bearing mice and was found to affect the average vessel size and the total vascular area. ${ }^{40}$ The density of microvessels in the tumor remained unaffected. This was not the case in the human synovium-SCID model. Interestingly, vessel size did not respond to TSP2 overexpression, whereas vessel density declined promptly. It is not known whether heterogeneity exists for the microvessels built in synovial lesions. But, differential responsiveness of human microvascular endothelial cells and human umbilical vein endothelial cells to TSP2-mediated growth inhibition has been reported. ${ }^{41}$ Thus, murine and human microvessels may have quite distinct response patterns to TSP2.

Tissue injury, including inflammation, has been identified as a powerful inducer of TSP2 in murine tissues. In mice, TSP2 was strongly induced at the site of hypersensitivity reactions, ${ }^{39}$ in cutaneous wounds, ${ }^{42}$ and in foreign body reactions. ${ }^{43}$ Mesenchymal cells emerge as the 
Total vascular area (\%)

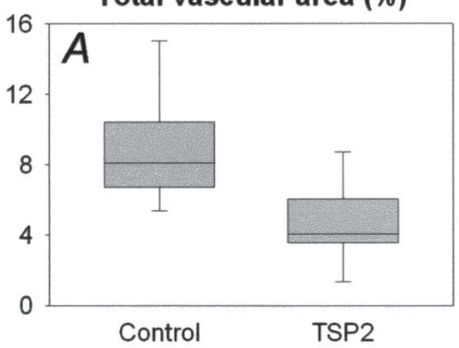

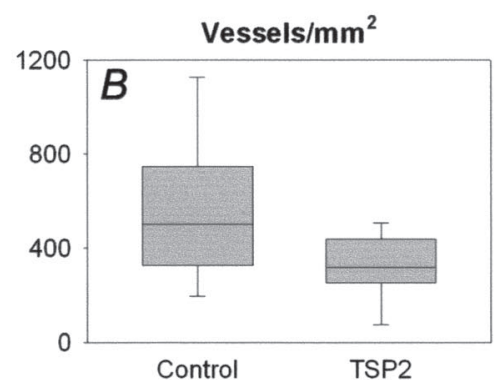

Average vessel size $\left(\mu \mathrm{m}^{2}\right)$

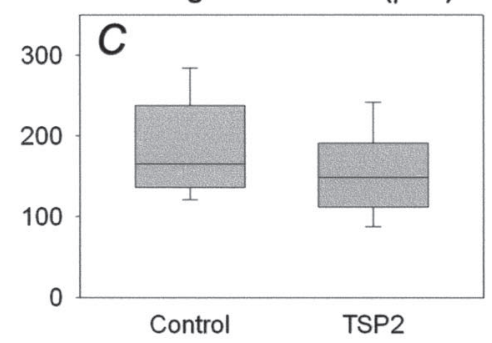

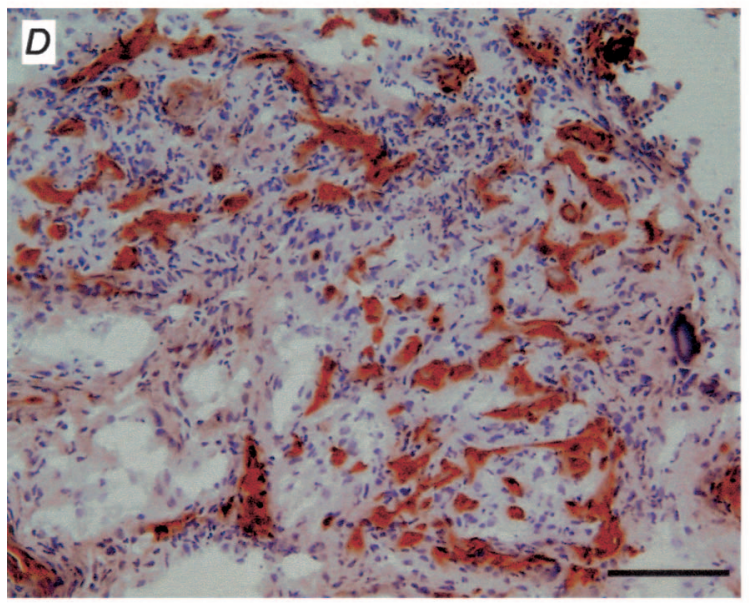

Control

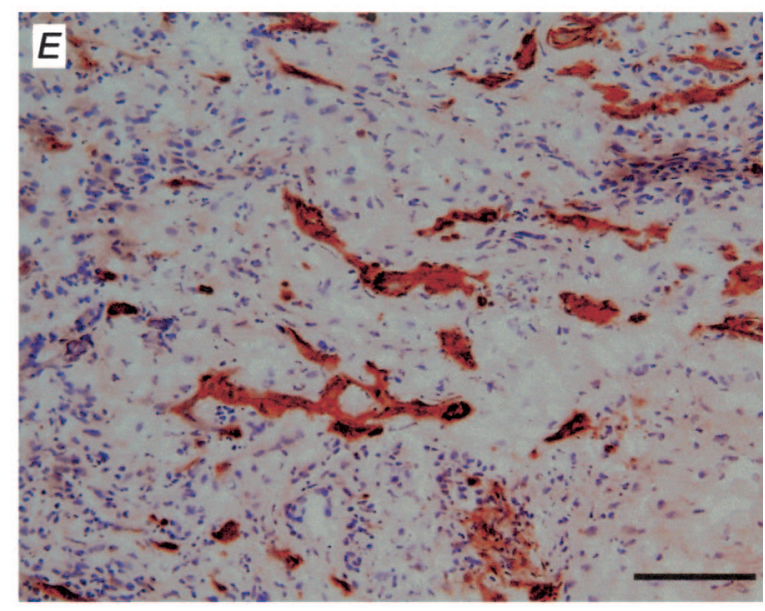

TSP2

Figure 7. Angio-inhibitory effects of TSP2 in vivo. Synovial grafts were explanted from chimeras 10 days after injection of TSP2-transfected NIH 3T3 fibroblasts or vector-transfected NIH 3T3 fibroblasts. Frozen sections were stained with anti-CD146 Ab (brown) to visualize endothelial cells. Computer-assisted morphometric analysis was used to quantify the total vascular area, the vessel density, and the average vessel size. Results are shown as box plots with medians, 25 th, and 75 th percentiles as boxes and 10th and 90th percentiles as whiskers. A: In five independent experiments, TSP2 overexpression resulted in a significant reduction $(P<0.001)$ of the total vascular area. B: Vessel density was significantly reduced $(P<0.01)$ in TSP2-treated synovial tissue as compared to controls. C: The average vessel size was unaffected $(P=$ NS) by TSP2. D and E: Representative tissue stains for CD146 in control synovial grafts $(\mathbf{D})$ and TSP2-treated synovial grafts (E) are shown. Scale bars, $100 \mu \mathrm{m}$.

common producer of TSP2 in all of these models, but increased numbers of TSP2-positive blood vessels were also reported in the cutaneous hypersensitivity reactions. ${ }^{39}$ In the lesion of rheumatoid synovitis, synovial fibroblasts stained positive for TSP2 and fibroblast cell lines established from digested synovial biopsies were strongly positive by Western blotting, as well as by immunohistochemistry. Thus, synovial fibroblasts as the producers of this highly effective modulator of angiogenesis and inflammation would have a center place in defining the susceptibility of the synovial membrane toward immunological attack. Normal synovial membrane may be protected from invasion by immunocompetent cells through natural anti-angiogenic and anti-inflammatory mechanisms, including the local production of TSP2 by site-specific fibroblast populations.

The question then arises how the tissue production of TSP2 is being regulated in the physiological state and how the immune system overcomes this natural protection. The finding that certain types of synovitis, such as $\mathrm{GC}^{+}$synovitis, are characterized by low levels of TSP2 production may provide valuable clues. The GC-forming type of synovitis is associated with high tissue concentrations of IFN- $\gamma$ and TNF- $\alpha$. Also, LT- $\alpha_{1} \beta_{2}$ is exclusively generated in rheumatoid lesions with $\mathrm{GCs} .{ }^{6} \mathrm{LT}-\beta$ produc- tion has been assigned to mantle zone B cells and a small population of $T$ cells. ${ }^{6}$ The different variants of rheumatoid synovitis also display variations in the production of DC-derived chemokines and cytokines. In essence, the populations of $\mathrm{T}$ cells, B cells, and macrophages that accumulate in rheumatoid lesions with highly complex lymphoid microstructures are functionally distinct from those that occupy diffuse synovial lesions. We have preliminary data that $\mathrm{T}$ cells can modulate the production of TSP2 by synovial fibroblasts. Such a mechanism would assign primary responsibility to the immune system in overcoming a natural protective mechanism in the synovial microenvironment.

In synovial grafts harvested from TSP2-treated chimeras, T-cell infiltrates were reduced and IFN- $\gamma$ production declined to minimal levels. Because the chimeras possess no circulating human lymphocytes, all effects of TSP2 on the rheumatoid infiltrates must reflect events in the lesion, excluding inhibition of T-cell recruitment as a possible mechanism. The loss of IFN- $\gamma$ may be an indirect effect secondary to $\mathrm{T}$-cell depletion because $\mathrm{T}$ cells are the source of this proinflammatory cytokine in the lesions. However, the reduction of IFN- $\gamma$ was disproportional to the decline in tissue-residing T cells. It is therefore possible that TSP2 also has a direct effect on the 

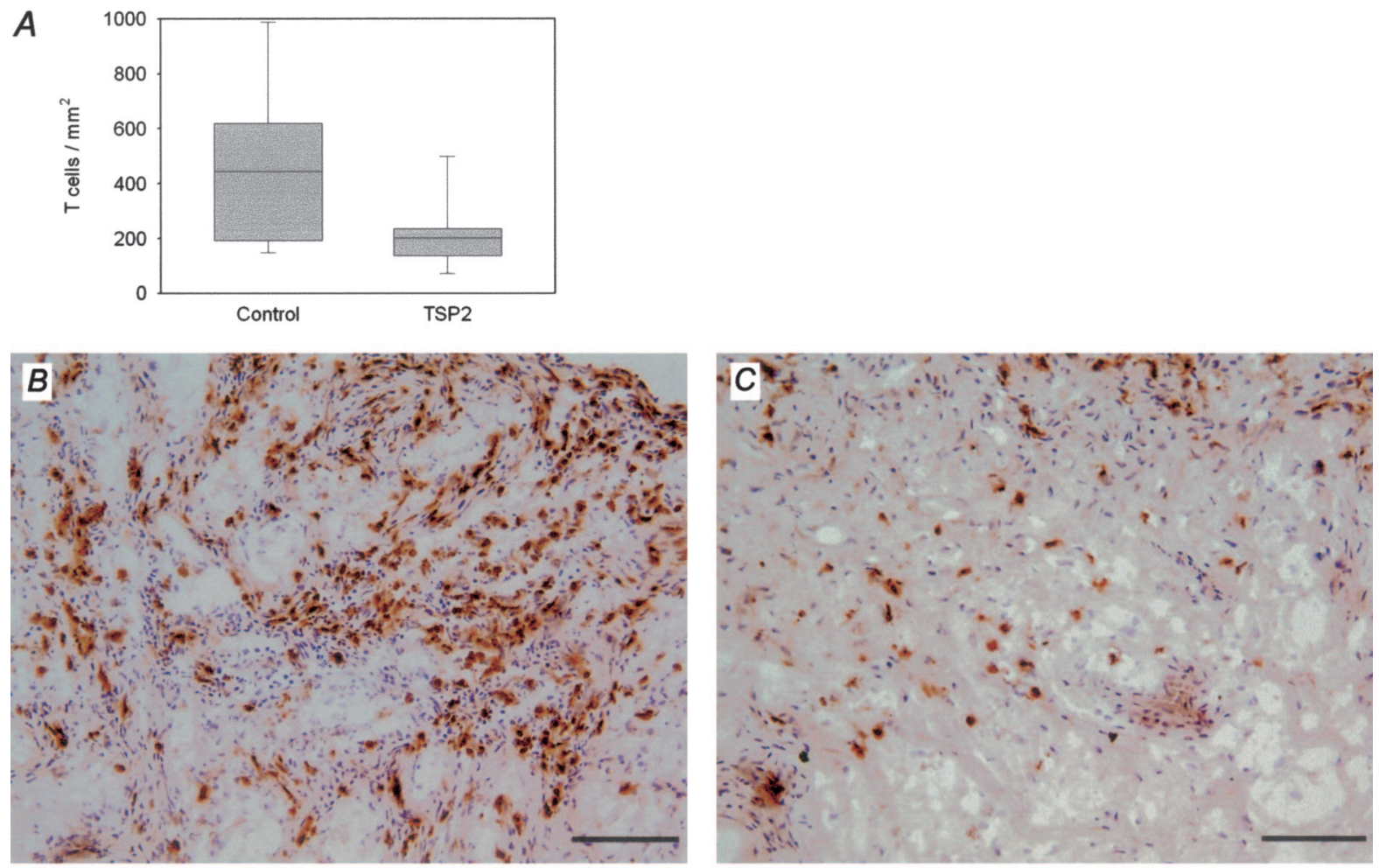

$D$
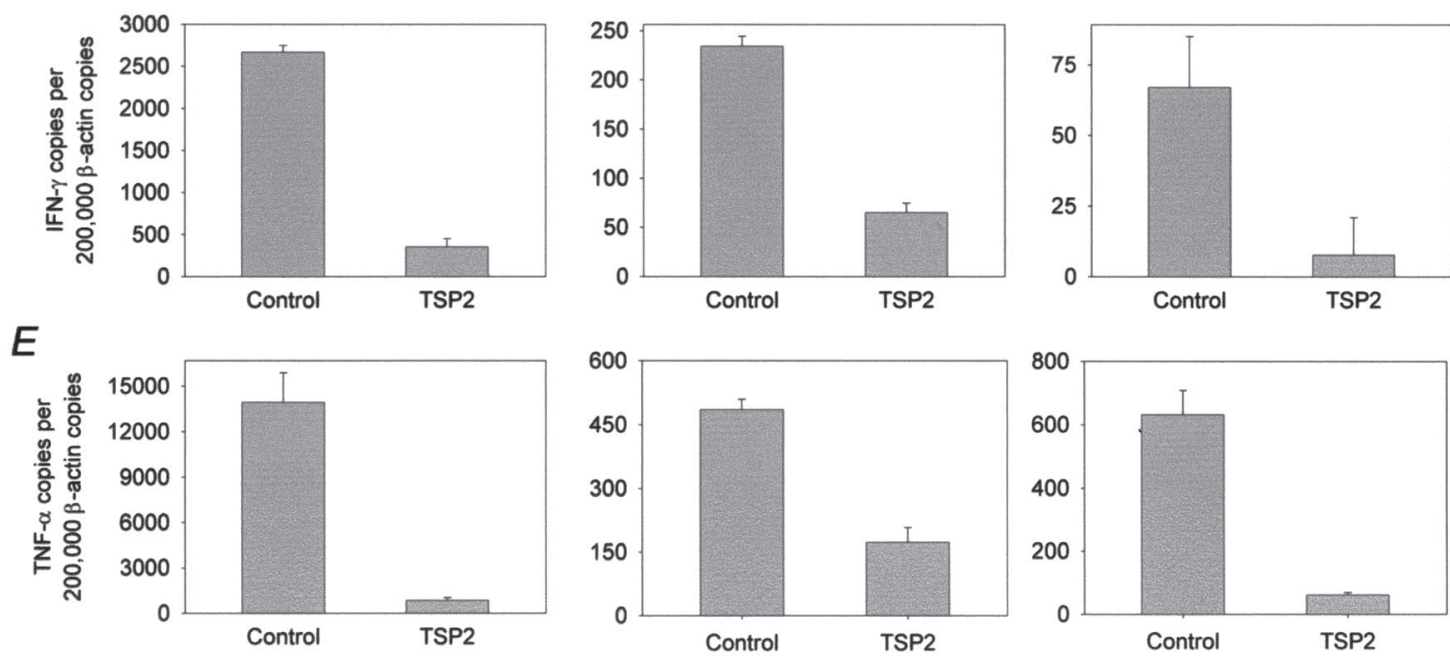

Figure 8. Anti-inflammatory effects of TSP2 in vivo. Human synovium-SCID chimeras were injected with TSP2- or vector-transfected fibroblasts as described in Figure 7. Synovial grafts were explanted after 10 days. Frozen tissue sections were stained with anti-CD3 Ab to determine the density of tissue-infiltrating T cells. A: TSP2 overexpression caused a marked reduction $(P<0.005)$ in T-cell density. $\mathbf{B}$ and $\mathbf{C}$ : Representative tissue stains for $\mathrm{CD} 3^{+} \mathrm{T}$ cells from one of four independent experiments are shown. Tissue explants from chimeras injected with vector-transfected fibroblasts maintained prominent lymphoid clusters with dense T-cell infiltrates (B) whereas TSP2 overexpression resulted in the loss of tissue-residing T cells $(\mathbf{C})$. To quantify proinflammatory cytokines, tissue extracts were prepared from explanted synovial grafts. Transcripts for $\beta$-actin, IFN- $\gamma$, and TNF- $\alpha$ were quantified by real-time PCR. Concentrations of IFN- $\gamma$ and TNF- $\alpha$ transcripts were adjusted to $2 \times 10^{5} \beta$-actin copies. Three of four independent experiments are shown. D: On overexpression of TSP2 in vivo, IFN- $\gamma$ transcripts fell to minimal levels. E: Similarly, TNF- $\alpha$-specific sequences decreased markedly in TSP2-treated tissues as compared to controls. Scale bars, $100 \mu \mathrm{m}$ (B and C).

production of IFN- $\gamma$. Similarly, TNF- $\alpha$ production was profoundly suppressed after therapy with TSP2. TNF- $\alpha$ in rheumatoid synovium derives from several cell types, mostly from activated macrophages and synovial fibroblasts. ${ }^{44,45}$ How TSP2 can affect the production of TNF- $\alpha$ and whether this effect is unique to RA requires further study. Macrophages in the synovial lesions express CD36 ${ }^{46}$ and thus are potential targets for TSP-mediated effects. T cells have been described to possess at least three distinct receptors for TSP1. ${ }^{4-50}$ TSP1 and TSP2 share multiple integrin recognition sites and recombinant portions of TSP 1 and TSP 2 bind to $\alpha_{4} \beta_{1}$ on T cells. ${ }^{51}$ TSPS can differentially modulate T-cell behavior and do so by using distinct surface receptors. TSP-mediated T-cell stimulation through the integrin $\alpha_{4} \beta_{1}$ leads to enhanced T-cell adhesion, chemotaxis, and MMP gene expression. 
Conversely, binding of CD47 by TSP1 results in an inhibitory signal interfering with T-cell antigen receptor signaling, ${ }^{52} \mathrm{~T}$ cell proliferation, ${ }^{53}$ and human dendritic cell activation. ${ }^{54}$ TSP1-mediated triggering of CD47 also inhibits the development of naive T cells into Th1 effector cells. ${ }^{55}$ Thus, multiple pathways exist through which TSP2 could directly affect T-cell function in the rheumatoid lesion. CD47 is abundantly expressed on $\mathrm{CD} 4^{+} \mathrm{T}$ cells that have been identified as critical regulator cells in the synovial lesions and that are characterized by the loss of the co-stimulatory molecule CD28. ${ }^{46,56}$

It remains to be studied whether treatment with TSP2 can be developed into a therapeutic strategy for managing RA. Cell-based TSP2 gene therapy may provide a unique opportunity to have more prolonged therapeutic effects. TSP2 is a physiological component of the synovial microenvironment. Thus, the therapeutic approaches using the natural anti-angiogenic and anti-inflammatory properties of this protein may be much more beneficial for the patient than tolerating the side effects of systemic immunosuppressive effects.

\section{Acknowledgments}

We thank Dr. A. Vallejo for technical advice and L. Arneson for secretarial support.

\section{References}

1. Marrack P, Kappler J, Kotzin BL: Autoimmune disease: why and where it occurs. Nat Med 2001, 7:899-905

2. McInnes IB: Rheumatoid arthritis. From bench to bedside. Rheum Dis Clin North Am 2001, 27:373-387

3. Schroder AE, Greiner A, Seyfert C, Berek C: Differentiation of B cells in the nonlymphoid tissue of the synovial membrane of patients with rheumatoid arthritis. Proc Natl Acad Sci USA 1996, 93:221-225

4. Weyand CM, Kang YM, Kurtin PJ, Goronzy JJ: The power of the third dimension: tissue architecture and autoimmunity in rheumatoid arthritis. Curr Opin Rheumatol 2003, 15:259-266

5. Klimiuk PA, Goronzy JJ, Bjornsson J, Beckenbaugh RD, Weyand CM: Tissue cytokine patterns distinguish variants of rheumatoid synovitis. Am J Pathol 1997, 151:1311-1319

6. Takemura S, Braun A, Crowson C, Kurtin PJ, Cofield RH, O'Fallon WM, Goronzy JJ, Weyand CM: Lymphoid neogenesis in rheumatoid synovitis. J Immunol 2001, 167:1072-1080

7. Klimiuk PA, Sierakowski S, Latosiewicz R, Cylwik B, Skowronski J, Chwiecko J: Serum cytokines in different histological variants of rheumatoid arthritis. J Rheumatol 2001, 28:1211-1217

8. Page G, Lebecque S, Miossec P: Anatomic localization of immature and mature dendritic cells in an ectopic lymphoid organ: correlation with selective chemokine expression in rheumatoid synovium. J Immunol 2002, 168:5333-5341

9. Kang YM, Zhang X, Wagner UG, Yang H, Beckenbaugh RD, Kurtin PJ, Goronzy JJ, Weyand CM: CD8 T cells are required for the formation of ectopic germinal centers in rheumatoid synovitis. J Exp Med 2002, 195:1325-1336

10. Wagner UG, Kurtin PJ, Wahner A, Brackertz M, Berry DJ, Goronzy JJ, Weyand CM: The role of CD8 + CD4OL + T cells in the formation of germinal centers in rheumatoid synovitis. J Immunol 1998, 161:63906397

11. Newton JL, Harney SM, Wordsworth BP, Brown MA: A review of the MHC genetics of rheumatoid arthritis. Genes Immun 2004, 5:151-157

12. Weyand CM, Hicok KC, Conn DL, Goronzy JJ: The influence of HLA-DRB1 genes on disease severity in rheumatoid arthritis. Ann Intern Med 1992, 117:801-806

13. Yen JH, Moore BE, Nakajima T, Scholl D, Schaid DJ, Weyand CM,
Goronzy JJ: Major histocompatibility complex class I-recognizing receptors are disease risk genes in rheumatoid arthritis. J Exp Med 2001, 193:1159-1167

14. Snyder MR, Lucas M, Vivier E, Weyand CM, Goronzy JJ: Selective activation of the c-Jun $\mathrm{NH} 2$-terminal protein kinase signaling pathway by stimulatory KIR in the absence of KARAP/DAP12 in CD4+ T cells. J Exp Med 2003, 197:437-449

15. Groh V, Bruhl A, El-Gabalawy H, Nelson JL, Spies T: Stimulation of T cell autoreactivity by anomalous expression of NKG2D and its MIC ligands in rheumatoid arthritis. Proc Natl Acad Sci USA 2003, 100: 9452-9457

16. Ji H, Gauguier D, Ohmura K, Gonzalez A, Duchatelle V, Danoy P, Garchon HJ, Degott C, Lathrop M, Benoist C, Mathis D: Genetic influences on the end-stage effector phase of arthritis. J Exp Med 2001, 194:321-330

17. Grant EP, Picarella D, Burwell T, Delaney T, Croci A, Avitahl N, Humbles AA, Gutierrez-Ramos JC, Briskin M, Gerard C, Coyle AJ: Essential role for the C5a receptor in regulating the effector phase of synovial infiltration and joint destruction in experimental arthritis. $J$ Exp Med 2002, 196:1461-1471

18. Weyand CM, Kurtin PJ, Goronzy JJ: Ectopic lymphoid organogenesis: a fast track for autoimmunity. Am J Pathol 2001, 159:787-793

19. Koch AE, Harlow LA, Haines GK, Amento EP, Unemori EN, Wong WL, Pope RM, Ferrara N: Vascular endothelial growth factor. A cytokine modulating endothelial function in rheumatoid arthritis. J Immunol 1994, 152:4149-4156

20. Koch AE: Angiogenesis as a target in rheumatoid arthritis. Ann Rheum Dis 2003, 62(Suppl 2):S60-S67

21. Paleolog EM, Fava RA: Angiogenesis in rheumatoid arthritis: implications for future therapeutic strategies. Springer Semin Immunopathol 1998, 20:73-94

22. Fearon U, Griosios K, Fraser A, Reece R, Emery P, Jones PF, Veale DJ: Angiopoietins, growth factors, and vascular morphology in early arthritis. J Rheumatol 2003, 30:260-268

23. Parangi S, O'Reilly M, Christofori G, Holmgren L, Grosfeld J, Folkman $J$, Hanahan D: Antiangiogenic therapy of transgenic mice impairs de novo tumor growth. Proc Natl Acad Sci USA 1996, 93:2002-2007

24. Fava RA, Olsen NJ, Spencer-Green G, Yeo KT, Yeo TK, Berse B, Jackman RW, Senger DR, Dvorak HF, Brown LF: Vascular permeability factor/endothelial growth factor (VPF/VEGF): accumulation and expression in human synovial fluids and rheumatoid synovial tissue. $J$ Exp Med 1994, 180:341-346

25. Gravallese EM, Pettit AR, Lee R, Madore R, Manning C, Tsay A, Gaspar J, Goldring MB, Goldring SR, Oettgen P: Angiopoietin-1 is expressed in the synovium of patients with rheumatoid arthritis and is induced by tumour necrosis factor alpha. Ann Rheum Dis 2003, 62:100-107

26. Uchida T, Nakashima M, Hirota Y, Miyazaki Y, Tsukazaki T, Shindo H Immunohistochemical localisation of protein tyrosine kinase receptors Tie-1 and Tie-2 in synovial tissue of rheumatoid arthritis: correlation with angiogenesis and synovial proliferation. Ann Rheum Dis 2000, 59:607-614

27. Iruela-Arispe ML, Bornstein $\mathrm{P}$, Sage $\mathrm{H}$ : Thrombospondin exerts an antiangiogenic effect on cord formation by endothelial cells in vitro. Proc Natl Acad Sci USA 1991, 88:5026-5030

28. Bornstein P, Armstrong LC, Hankenson KD, Kyriakides TR, Yang Z Thrombospondin 2, a matricellular protein with diverse functions. Matrix Biol 2000, 19:557-568

29. O'Reilly MS, Holmgren L, Shing Y, Chen C, Rosenthal RA, Moses M, Lane WS, Cao Y, Sage EH, Folkman J: Angiostatin: a novel angiogenesis inhibitor that mediates the suppression of metastases by a Lewis lung carcinoma. Cell 1994, 79:315-328

30. O'Reilly MS, Boehm T, Shing Y, Fukai N, Vasios G, Lane WS, Flynn E, Birkhead JR, Olsen BR, Folkman J: Endostatin: an endogenous inhibitor of angiogenesis and tumor growth. Cell 1997, 88:277-285

31. Pike SE, Yao L, Jones KD, Cherney B, Appella E, Sakaguchi K, Nakhasi H, Teruya-Feldstein J, Wirth P, Gupta G, Tosato G: Vasostatin, a calreticulin fragment, inhibits angiogenesis and suppresses tumor growth. J Exp Med 1998, 188:2349-2356

32. Kyriakides TR, Zhu YH, Yang Z, Bornstein P: The distribution of the matricellular protein thrombospondin 2 in tissues of embryonic and adult mice. J Histochem Cytochem 1998, 46:1007-1015 
33. Lawler J: The functions of thrombospondin-1 and -2. Curr Opin Cell Biol 2000, 12:634-640

34. Kyriakides TR, Bornstein P: Matricellular proteins as modulators of wound healing and the foreign body response. Thromb Haemost 2003, 90:986-992

35. Kyriakides TR, Zhu YH, Smith LT, Bain SD, Yang Z, Lin MT, Danielson KG, lozzo RV, LaMarca M, McKinney CE, Ginns El, Bornstein P: Mice that lack thrombospondin 2 display connective tissue abnormalities that are associated with disordered collagen fibrillogenesis, an increased vascular density, and a bleeding diathesis. J Cell Biol 1998, 140:419-430

36. Kyriakides TR, Zhu YH, Yang Z, Huynh G, Bornstein P: Altered extracellular matrix remodeling and angiogenesis in sponge granulomas of thrombospondin 2-null mice. Am J Pathol 2001, 159:1255-1262

37. Agah A, Kyriakides TR, Lawler J, Bornstein P: The lack of thrombospondin-1 (TSP1) dictates the course of wound healing in doubleTSP1/TSP2-null mice. Am J Pathol 2002, 161:831-839

38. Hawighorst T, Velasco P, Streit M, Hong YK, Kyriakides TR, Brown LF, Bornstein P, Detmar M: Thrombospondin-2 plays a protective role in multistep carcinogenesis: a novel host anti-tumor defense mechanism. EMBO J 2001, 20:2631-2640

39. Lange-Asschenfeldt $B$, Weninger W, Velasco P, Kyriakides TR, von Andrian UH, Bornstein P, Detmar M: Increased and prolonged inflammation and angiogenesis in delayed-type hypersensitivity reactions elicited in the skin of thrombospondin-2-deficient mice. Blood 2002, 99:538-545

40. Streit M, Stephen AE, Hawighorst T, Matsuda K, Lange-Asschenfeldt B, Brown LF, Vacanti JP, Detmar M: Systemic inhibition of tumor growth and angiogenesis by thrombospondin-2 using cell-based antiangiogenic gene therapy. Cancer Res 2002, 62:2004-2012

41. Armstrong LC, Bjorkblom B, Hankenson KD, Siadak AW, Stiles CE, Bornstein P: Thrombospondin 2 inhibits microvascular endothelial cell proliferation by a caspase-independent mechanism. Mol Biol Cell 2002, 13:1893-1905

42. Kyriakides TR, Tam JW, Bornstein P: Accelerated wound healing in mice with a disruption of the thrombospondin 2 gene. J Invest Dermatol 1999, 113:782-787

43. Kyriakides TR, Leach KJ, Hoffman AS, Ratner BD, Bornstein P: Mice that lack the angiogenesis inhibitor, thrombospondin 2, mount an altered foreign body reaction characterized by increased vascularity. Proc Natl Acad Sci USA 1999, 96:4449-4454

44. Smeets TJ, Barg EC, Kraan MC, Smith MD, Breedveld FC, Tak PP: Analysis of the cell infiltrate and expression of proinflammatory cytokines and matrix metalloproteinases in arthroscopic synovial biopsies: comparison with synovial samples from patients with end stage, destructive rheumatoid arthritis. Ann Rheum Dis 2003, 62:635638

45. Matsuno H, Yudoh K, Katayama R, Nakazawa F, Uzuki M, Sawai T, Yonezawa T, Saeki Y, Panayi GS, Pitzalis C, Kimura T: The role of TNF-alpha in the pathogenesis of inflammation and joint destruction in rheumatoid arthritis (RA): a study using a human RA/SCID mouse chimera. Rheumatology (Oxford) 2002, 41:329-337

46. Vallejo AN, Mugge LO, Klimiuk PA, Weyand CM, Goronzy JJ: Central role of thrombospondin- 1 in the activation and clonal expansion of inflammatory T cells. J Immunol 2000, 164:2947-2954

47. Brown EJ, Frazier WA: Integrin-associated protein (CD47) and its ligands. Trends Cell Biol 2001, 11:130-135

48. Dawson DW, Pearce SF, Zhong R, Silverstein RL, Frazier WA, Bouck NP: CD36 mediates the in vitro inhibitory effects of thrombospondin-1 on endothelial cells. J Cell Biol 1997, 138:707-717

49. Chen H, Strickland DK, Mosher DF: Metabolism of thrombospondin 2. Binding and degradation by 3 t3 cells and glycosaminoglycan-variant Chinese hamster ovary cells. J Biol Chem 1996, 271:15993-15999

50. Chen H, Sottile J, O'Rourke KM, Dixit VM, Mosher DF: Properties of recombinant mouse thrombospondin 2 expressed in Spodoptera cells. J Biol Chem 1994, 269:32226-32232

51. Li Z, Calzada MJ, Sipes JM, Cashel JA, Krutzsch HC, Annis DS, Mosher DF, Roberts DD: Interactions of thrombospondins with alpha4beta1 integrin and CD47 differentially modulate T cell behavior. J Cell Biol 2002, 157:509-519

52. Li Z, He L, Wilson K, Roberts D: Thrombospondin-1 inhibits TCRmediated T lymphocyte early activation. J Immunol 2001, 166:24272436

53. Beppu R, Nakamura K, Miyajima-Uchida H, Kuroki M, Khare PD, Yamauchi Y, Yamashita Y, Shirakusa T: Soluble thrombospondin-1 suppresses $T$ cell proliferation and enhances IL-10 secretion by antigen presenting cells stimulated with phytohemagglutinin. Immunol Invest 2001, 30:143-156

54. Doyen V, Rubio M, Braun D, Nakajima T, Abe J, Saito H, Delespesse G, Sarfati M: Thrombospondin 1 is an autocrine negative regulator of human dendritic cell activation. J Exp Med 2003, 198:1277-1283

55. Avice MN, Rubio M, Sergerie M, Delespesse G, Sarfati M: CD47 ligation selectively inhibits the development of human naive $T$ cells into Th1 effectors. J Immunol 2000, 165:4624-4631

56. Vallejo AN, Yang H, Klimiuk PA, Weyand CM, Goronzy JJ: Synoviocyte-mediated expansion of inflammatory $T$ cells in rheumatoid synovitis is dependent on CD47-thrombospondin 1 interaction. J Immunol 2003, 171:1732-1740 